\title{
Dependence of the mined ores quality on the geological structure and properties of the hanging wall rocks
}

\author{
Mykhailo Petlovanyi ${ }^{1}$, Vladyslav Ruskykh ${ }^{1}$, Serhii Zubko ${ }^{2}$, and Volodymyr Medianyk ${ }^{1}$ \\ ${ }^{1}$ Dnipro University of Technology, Department of Mining Engineering and Education, \\ 19 Yavornytskoho, 49005 Dnipro, Ukraine \\ ${ }^{2}$ PJSC “Zaporizhzhia Iron Ore Plant”, Roadway Veselivske, 7 km, 71674 Mala Bilozirka-4 village, \\ Zaporizhzhia region, Ukraine
}

\begin{abstract}
Paper presents the research results of the relationship revealed between the mined ore dilution factors and the geological structure and properties of the hanging wall rocks. The research methodology is in the analysis of the structure and properties of the hanging wall rocks, the technological parameters of the stopes in contact with the host rocks, the processing of actual surveying data of the rockfall volumes and dilution factors, the construction of a 3D model of the mined floor with the stopes divided according to the sequence of mining. The peculiarities have been revealed of changing the geological structure along the strike of the ore deposit with a characteristic distinguished tendency to decreasing the hardness of hanging wall rocks, the angle of the ore deposit slope, increasing the deposit thickness and replacing the morphological composition of the rocks with the division into 3 characteristic differing areas. New patterns and empirical equations have been determined for changing the ore dilution value in the primary stopes depending on the type, hardness coefficient and the contact area of the hanging wall rocks with the inclined outcropping of the stopes. A multiple regression equation has been obtained of the relation between the primary stopes dilution with the rocks hardness within $f=11-15$ and the contact area of the stopes with rocks $780-2010 \mathrm{~m}^{2}$. The regression model variability of $85.96 \%$ evidences its reliability and representativeness. The methodological approach proposed in the paper can be used to develop an improved methodology for predicting the mined ores dilution when mining the Pivdenno-Bilozirske field, supplemented by a more complete data set to increase reliability.
\end{abstract}

\section{Introduction}

The subsoil of Ukraine is provided with significant iron ore reserves. Ukraine holds the first place in the world in terms of geological reserves of iron ores, which are assessed at 30 billion tons, and per a pure iron content it holds the fourth place after Russia, Brazil

\footnotetext{
${ }^{*}$ Corresponding author: petlyovanyi1986@gmail.com
} 
and Australia [1,2]. The mining industry, which is a part of the mining and metallurgical complex, occupies a leading position in the Ukrainian economy and provides considerable foreign exchange earnings from the iron ore raw materials export. Thus, according to the State Fiscal Service of Ukraine, the export of iron ore raw materials and concentrate in 2019 amounted to 3.0 billion tons. The fresh raw material for the mining and metallurgical complex functioning is crude iron ore, which is mined both by underground and surface mining methods. Sustainable extraction of ferrous metals, as well as coal and hydrocarbon gases, is able to ensure the efficient functioning of the country's industrial complex [3 - 5].

In Ukraine, about $10 \%$ of all iron ore, which is 15 million tons, is mined by underground method, mainly, in the Kryvorizke ( 8 mines) and Bilozirske fields ( 1 mine). In Kryvbas, iron ores are mined using a stope system of mining (55\%) and sub-level caving method (45\%). In the Bilozirske field, a stope system of mining is used with consolidating backfilling of the mined-out space (100\%) [6-8]. PJSC "Zaporizhzhia Iron Ore Plant" is one of the mining enterprises that, using underground ore mining and a method of consolidating backfilling, develops rich iron ores of the Bilozirske field with an iron content of more than $60 \%$. Specific plant weight in underground mining in Ukraine is $25-30 \%[9,10]$. An obvious advantage when using consolidating backfilling is its low level of waste, since industrial waste is disposed of in the underground space, and the environmental impact of mining operations is minimized [11 - 14].

The most important indicator characterizing the effectiveness of stope systems of mining with consolidating backfilling is the mined ore dilution factor [15, 16]. When mining the steeply dipping ore deposits, the weak footwall rocks and hanging wall rocks, as well as an insufficiently strong backfill massif are collapsed under the seismic impact of blasting operations, which leads to the broken ore dilution [17-19]. The value of the ore mass dilution by collapsed rocks depends on the geological structure and stability of the rock massif, as well as the technological parameters of the mining system [20-22]. It is an urgent issue to constantly take into account the geological factors when planning the development of ore [23, 24]. and energy minerals [25, 26].

In case of stope systems of mining with a backfilling, the ore deposit is mined by primary stopes and secondary stopes $[27,28]$. The difference in mining conditions of the primary stopes is that their reserves are mined while surrounded by the ore and rock massifs, and the secondary stope - while surrounded by the ore, rock and backfill massifs. The quality level of ore reserves mining from the stopes, which are developed primary in contact with the natural geological massif, is extremely important, since the sale of this merchantable ore forms the primary profit of the enterprise.

For successful export, and, hence, profitability, the market prices for iron ore are set with account of the iron content in it. Therefore, it is necessary to observe quality characteristics in order to avoid the loss of its competitiveness in the market $[29,30]$. In addition, the geological environment influence (the rocks of the hanging wall or footwall) on the quality of ore mining from the primary stopes is of interest from the scientific point of view.

In the world practice of mining the steeply dipping ore deposits, in case when the similar problems arise, a solution is found to use the technology of strengthening the hanging wall rocks with cablebolts $[31,32]$. However, for their rational use, the primary task is to determine the stopes exposed to high dilution factor.

Thus, an important stage in the designing and planning of ore mining in the floor is to monitor and predict the factors of ore dilution caused by host rocks during mining the primary stopes. Taking into account the systematization and generalization of the data set on ore dilution in stopes with the geological conditions of these stopes mining, a basis is formed for optimizing the parameters of the stope system of mining. 


\section{Research object characteristic and setting of a problem}

The object of research is the development of a thick ore body in the Pivdenno-Bilozirske field, rich in hematite-martite ores under the influence of the geological environment, which is mined by the PJSC “Zaporizhzhia Iron Ore Plant” (Fig. 1).

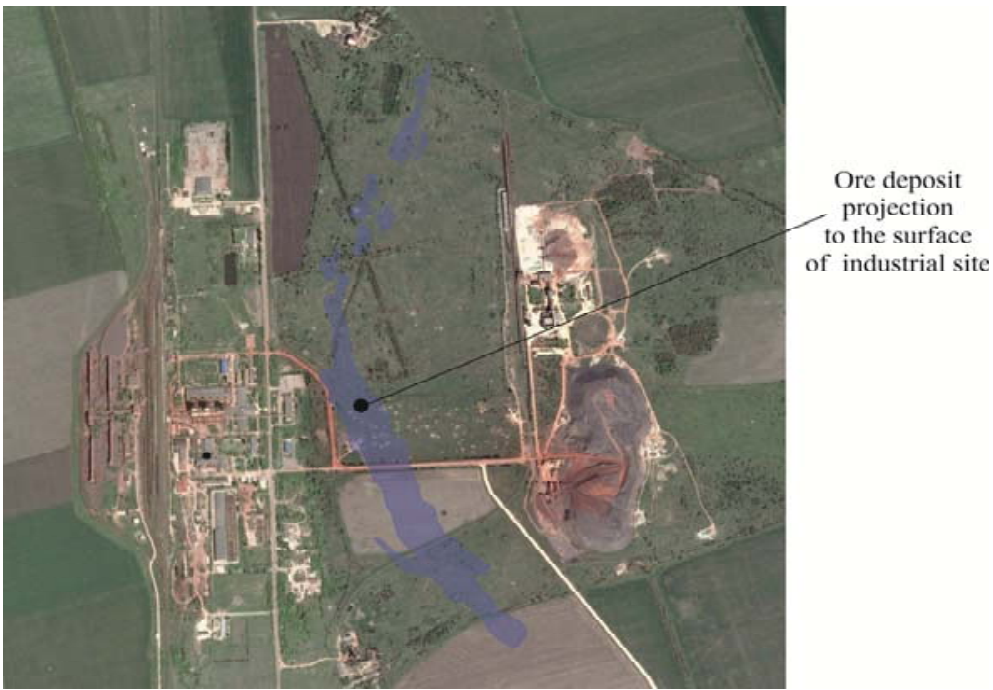

Fig. 1. "Holovna" ore deposit projection to the surface of the mine's industrial site.

The incline of "Holovna" ore deposit is eastern. The slope angle of the ore-rock stratum is from 60 to $80^{\circ}$ with a sheet-like form of bedding. The maximum deposit thickness is $150 \mathrm{~m}$ in the southern mine field wing, the minimum thickness in the north wing is $10 \mathrm{~m}$. In the footwall, the shale rocks occur of quartz-peach-sericitic composition with a strength of $60-90 \mathrm{MPa}$. In contact of ore with shale rocks, the interlayers of quartzites up to $10 \mathrm{~m}$ thick often occur. The hanging wall of the northern deposit area is represented by ferruginous quartzites, very strong, fractured and stable, with a strength of $120-160 \mathrm{MPa}$. In the southern hanging wall area, the rocks occur, which are similar in structure to the footwall rocks. The central zone is transition one, that is, both quartzites and shale rocks with a strength of $80-120 \mathrm{MPa}$ occur in it.

Thick ore body is developed by a stope system of mining with consolidating backfilling, mainly according to the "stope - pillar" scheme from the mine field centre towards its flanks. The stope (floor) height is $100-200 \mathrm{~m}$, the stopes width is $30 \mathrm{~m}$, the length, depending on the deposit thickness, is $30-60 \mathrm{~m}$. Depending on the thickness variation, $2-3$ stopes are arranged across the deposit strike, and reserves are mined from the hanging wall towards the footwall and vice versa.

Despite the use of an effective system of mining with consolidating backfilling, the problems of natural-technogenic massif stability have arisen in the course of ore reserves mining in the depth range of $480-940 \mathrm{~m}$. They were caused by the rock pressure increasing with depth, the difference in geological conditions along the deposit strike (changing the morphological composition of the rocks), the blasting operations impact on the massif, which have led to the collapse of rocks, ore and backfilling into the mined-out space of the stopes $[33,34]$. At the first stage of mining the stopes, which are in contact with the host rocks, the areas of rockfall formation are round in shape (Fig. 2). 


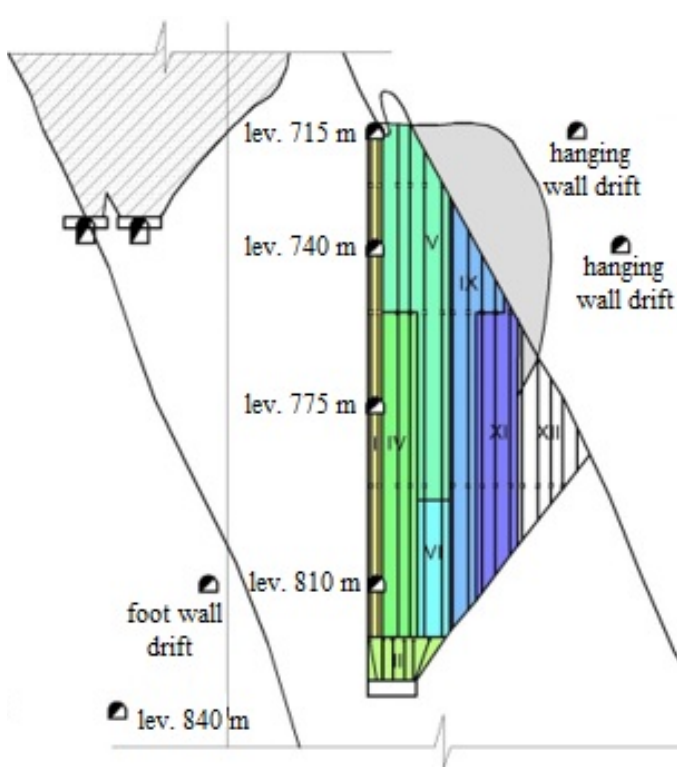

Fig. 2. Areas of rockfall formation in the hanging wall rocks when mining the ore from the primary stopes.

The rockfall, formed in the hanging wall and footwall, leads to worsening the mined ores quality, additional volumes of filling the cavities with a backfilling, and a deterioration in the operational condition of sublevel mine workings, through which people and underground transport constantly move $[35,36]$.

\section{Research methodology}

To identify the dependence of the geological structure of the ore deposit and host rocks on the dilution of ore mined from the primary stopes, a comprehensive methodological approach has been adopted. This approach includes a detailed analysis of the mining-andgeological structure and properties of the host rocks in the hanging wall, analysis of the technological parameters of stopes mined-out in contact with the host rocks, processing of actual surveying data of rockfall volumes and dilution factors, as well as constructing a 3D model of one of the Pivdenno-Bilozirske field floors.

Floor $740-840 \mathrm{~m}$ is adopted for study, the reserves of which are currently in intensive mining, where there is a representative sample in terms of mining the primary stopes, in particular. By means of digitizing the geological sheets of the deposit over horizons of 715 , $740,775,810$, and $840 \mathrm{~m}$, a 3D model has been constructed using the Autocad 2017 and 3D MAX software packages. This allows to present in detail the geological peculiarities of the ore deposit structure, as well as its contacts with the host rocks. Then, the ore deposit in the floor is divided along the corresponding surveying axes (north, south) into primary stopes and secondary stopes, according to the scheduling of mining operations (Fig. 3). In areas of increasing the deposit thickness of over $50 \mathrm{~m}$ across the strike, 2 stopes are arranged - from the side of hanging wall and footwall.

The geo-environment influence on the ore mining quality can be observed when mining the primary stopes, which are in contact with the hanging wall rocks, since from this side the mined stopes are effected by their direct pressure. 


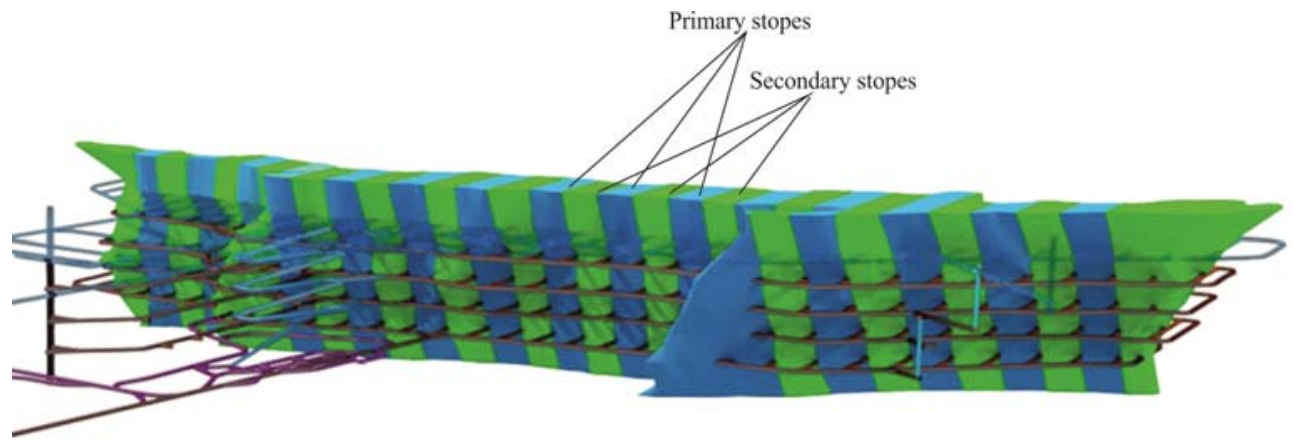

Fig. 3. Ore body in the floor divided into primary stopes and secondary stopes of mining ("stope pillar" scheme).

For this purpose, the morphological composition of the rocks, their hardness and stability, as well as the contact area with the inclined outcropping of the stopes, have been studied in detail. The geological factors influence on the footwall stopes dilution was not studied due to their significantly lower factors, in comparison with the hanging wall stopes.

The contact area of the hanging wall rocks with the stopes is determined analytically by product of such technological parameters of the stope as its width and the size of the inclined outcropping, determined with account of the slope angle. And after that, the result is refined by shooting the area in 3D MAX program (Fig. 4).

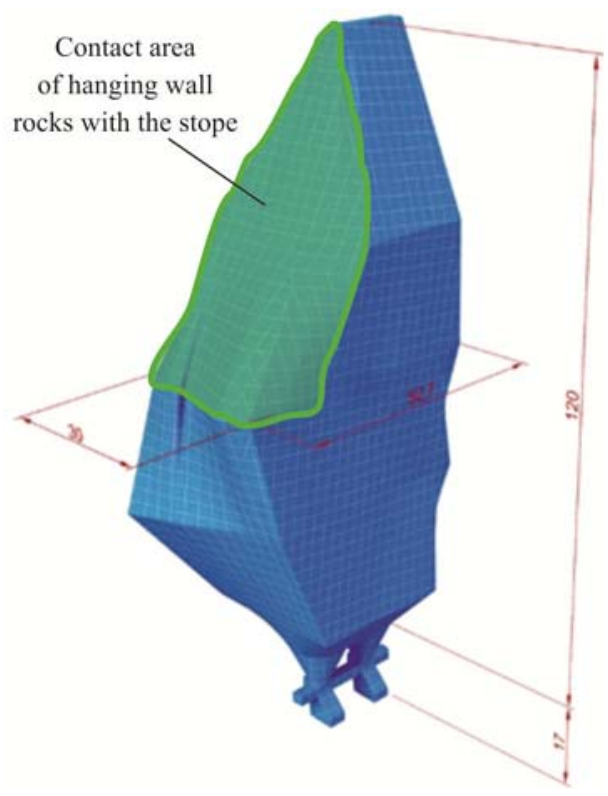

Fig. 4. Formation of a stope 3D-model for determining the contact area with the hanging wall rocks.

The geological structure and properties of the hanging wall rocks contacting with the studied stopes are studied by the length of the ore deposit strike based on the analysis of the geological data for each of the stopes. The primary stopes under study are arranged in the surveying axes 24 north to 15 south, and their certain geological and mining-engineering parameters are presented in Table 1. 
Table 1. The limits of certain geological and mining-engineering parameters of the primary stopes.

\begin{tabular}{|c|c|c|c|c|c|}
\hline \multirow{2}{*}{$\begin{array}{c}\text { Arrangement of } \\
\text { the primary stopes }\end{array}$} & $\begin{array}{c}\text { Number } \\
\text { of studied } \\
\text { stopes }\end{array}$ & \multirow{2}{*}{$\begin{array}{c}\text { Contact area } \\
\text { of rocks with } \\
\text { stopes, } \mathrm{m}^{2}\end{array}$} & \multicolumn{2}{|c|}{$\begin{array}{c}\text { Hanging wall rocks } \\
\text { hardness }\end{array}$} & \multirow{2}{*}{$\begin{array}{c}\text { Stability/ } \\
\text { fracturing }\end{array}$} \\
\cline { 4 - 5 } & shale rocks & quartzites & \\
of a deposit & 14 & $780-2000$ & $7-9$ & $13-15$ & Medium \\
\hline
\end{tabular}

\section{Research findings}

Through a detailed scientific and technical analysis, it has been determined that "Holovna" ore deposit in the depth interval of $640-1040 \mathrm{~m}$ along the length of its strike has 3 characteristic areas differing in geological structure and rock properties: northern, central, and southern areas. Further, for the floor $740-840 \mathrm{~m}$, the revealed ore deposit geological peculiarities are formulated.

The northern deposit area is characterized by high values of hardness coefficient up to $f=14-16$. The rocks of the hanging wall and footwall are represented by quartzites of the hematite-martite composition with hardness, mainly of medium stability and fracturing. The medium ore hardness is $f=9.5$. The deposit thickness in this zone is within $20-50 \mathrm{~m}$. The slope angle is within $70-80^{\circ}$. The deposit in this zone is split into several ore veins, which are separated by quartzites with a low iron content. The ore mined dilution in the stopes of the northern area usually does not exceed $3.0 \%$ and is caused primarily by the presence of rock interlayers in ore reserves mined by the explosion.

The central deposit area is characterized by the beginning of a change in the morphological rocks composition. In the footwall and hanging wall, with distance towards the southern part, quartzites are gradually replaced by quartz-peach-sericitic shale rocks with reduced hardness and rocks interbedding is observed. Therefore, the average hardness of these rocks in contact with the stopes is in the range $f=7-9$ to $8-10$ with the medium stability and fracturing. The ore body thickness here increases sharply, reaches the values of $100-$ $120 \mathrm{~m}$ and becomes persistent. The slope angle is in the range of $68-73^{\circ}$. The average ore hardness decreases and reaches $f=7.0$. Ore dilution by rocks is at the level of $3.0-7.0 \%$.

The southern deposit area is characterized by the fact that the ore body here occupies almost the entire iron ore horizon, the deposit thickness increases from the centre to the south from $60 \mathrm{~m}$ and reaches $130 \mathrm{~m}$, and the ore hardness is $f=6.5$. The host rocks, both in the hanging wall and in the footwall, are represented by shale rocks of quartz-chloritesericitic, quartz-sericite-chloritic and quartz-hematite-chloritic composition, with hardness of $f=7-9$ with medium stability and fracturing. At the end of the southern deposit area in a small section in the hanging wall rocks, there reappear quartzites $f=14-16$ with medium stability and fracturing. Ore dilution by rocks reaches $8-12 \%$.

The primary stopes analysed in the research are arranged in 3 different areas as follows: the northern area -5 ; the central area -3 , the southern area -6 .

The possible influence of the time of mining the stope on the factor of rocks collapse and ore dilution is also studied. There is no a clear dependence of the mined volumes on the time of collapse. It has been determined that by the time of collapse, more than $70 \%$ of the stope reserve is mined from the stopes (stopes: $1 / 5$ south $-88 \%, 2 / 5$ south $-71 \%, 2 / 9$ south $70 \%$ ). In the stopes $2 / 1$ south and $2 / 3$ south, $30 \%$ and $55 \%$, respectively, have been mined by the time of collapse. But this is primarily conditioned by the peculiarities of the mining order of ore reserves in the stope. There is practically no particular dependence from the influence of the time of mining the studied stopes:

- in the stope 2/9south - collapse in the roof and walls occurred after 17 months, by this time $70 \%$ of the stope reserve had been mined-out; 
- in the stope $2 / 5$ south - falls in the roof and walls occurred 10 months after the beginning of the stope operations. By this time $71 \%$ of the stope reserve had been mined-out;

- in the stope $2 / 3$ south - collapse in the roof and walls occurred after 8 months, by this time $55 \%$ of the stope reserve had been mined-out.

Thus, there is no significant influence of terms of the stope mining on the beginning of the stope space contours collapse. Based on the research performed, it has been concluded that the existing now terms of mining and the mined-out stope volumes do not have a significant influence by the time of collapse.

Through mathematical processing of ore dilution data in the stopes, the type, hardness coefficient, and the stopes area of the hanging wall rocks which contact with the inclined outcropping, new patterns of the correlation relationship of these parameters have been obtained.

It has been revealed that when mining the primary stopes, the dilution factors of the mined ore naturally increase with a decrease in the hardness of the hanging wall rocks and an increase in their contact area with the inclined outcropping of the stopes (Figs. 5 and 6).

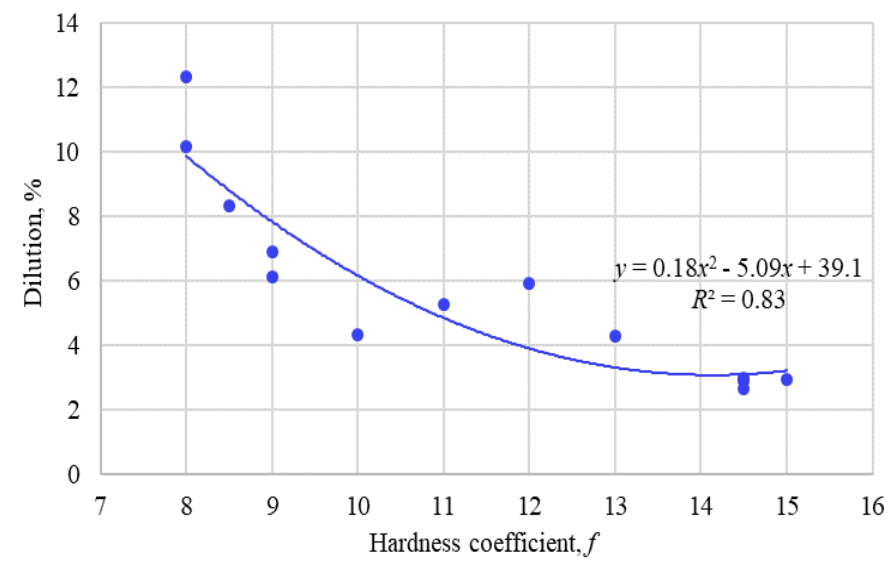

Fig. 5. Dependence of the mined ore dilution factor on the hardness of hanging wall rocks.

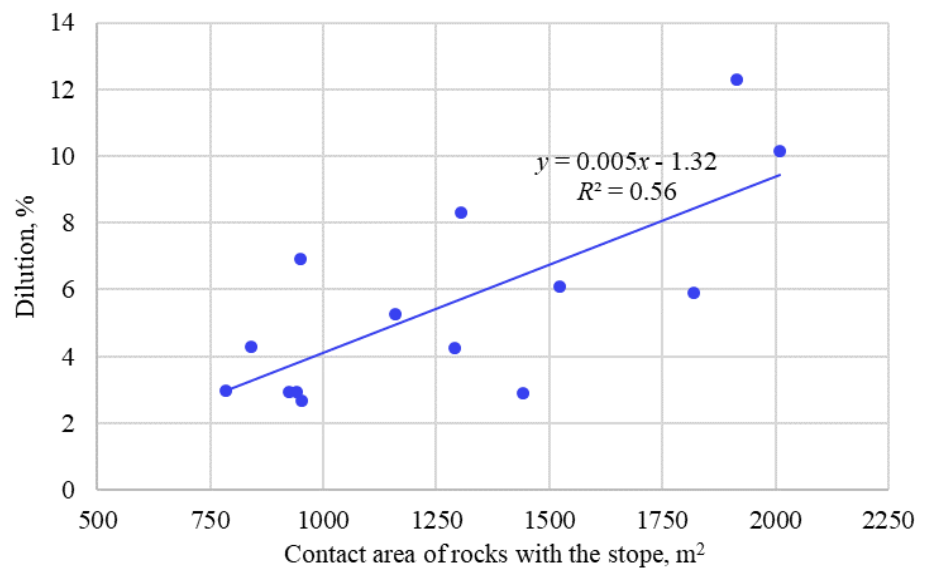

Fig. 6. Dependence of the mined ore dilution factor on the contact area with the hanging wall rocks.

When analysing Fig. 5, it can be seen that the mined ore dilution factor varies within $2.5-12.0 \%$, depending on the hardness of the hanging wall rocks contacting with the stope. This can be described by a polynomial law of the $2^{\text {nd }}$ order in the form 
$R=0.18 f^{2}-5.09 f+39.1$ with a sufficiently representative determination coefficient $R^{2}=0.83$. It should be noted such an important fact that with a decrease in the rocks hardness from $f=11$ to $f=8$, a sharp increase in dilution factor by 2.2 times is observed. However, with a decrease in hardness from $f=15$ to $f=11$, the dilution factor increases by 1.5 times. This is conditioned by the fact that in the hardness intervals $f=8-10$, the hanging wall rocks are represented by quartz-chlorite-sericitic shale rocks, which are prone to spalling and do not withstand significant areas of outcropping. At $f=11-15$, the hanging wall rocks are represented by massive ferruginous quartzites, which perform as a rock bridge and only in the case of an intensively developed system of fractures the rock bridge is divided into blocks.

When analysing Fig. 6, it can be seen a uniform linear correlation relationship between the dilution factor and the area of the hanging wall rocks contacting with the inclined outcropping of the stopes of the following form $R=0.005 S-1.32$, with a determination coefficient $R^{2}=0.56$. This evidences a slightly lower degree of influence on dilution in comparison with the rocks hardness, if they are considered separately.

To identify the complex degree of influence of the hardness and contact area of the hanging wall rocks with inclined outcropping of the stopes, based on a number of mathematical transformations, a multiple regression equation of the dependence between the stopes dilution of the floor 740-840 m with the rocks hardness within $f=8-15$ and the contact area of the stopes with the rocks $780-2010 \mathrm{~m}^{2}$ has been composed, which is as follows:

$$
Y=10.24-0.69 X_{1}+0.0027 X_{2},
$$

where $Y$ is predicted ore dilution factor, $\% ; X_{1}$ is hardness coefficient of the hanging wall rocks; $X_{2}$ is contact area of the hanging wall rocks with inclined outcropping of the stope, $\mathrm{m}^{2}$.

The equation statistical significance has been verified with the use of the determination coefficient and the Fisher's exact test. Since the actual value is $F>F_{k p}$, then the determination coefficient is statistically significant and the regression equation is statistically reliable. It has been determined that in the studied situation, $85.96 \%$ of the total $Y$ variability is explained by a change in factors $X_{1,2}$. The regression model variability of $85.96 \%$ indicates its reliability and representativeness, while the remaining $14 \%$ are other geological and mining-engineering factors or stochastic irregular processes, influencing probably to a lesser extent. Hence, it is difficult to take them into account due to lack of information about the mine rock massif (fracturing, water-cut, the presence of geological faults, etc.).

There is also the possibility of economic substantiation of the model parameters: an increase in hardness $f$ by 1 unit measure leads to a decrease in dilution $R$ at an average by 0.692 unit measures, and an increase in $S$ by 1 unit measure leads to an increase in $R$ at an average by 0.00268 unit measures.

Thus, in the performed research, based on a comprehensive geological and technological analysis of mining conditions of the primary stopes of the floor $740-840 \mathrm{~m}$, a close correlation relationship has been revealed between the broken ore dilution, the hardness and morphological composition of the hanging wall rocks, as well as their contact area with the stopes.

The methodological approach proposed in the paper can be used to develop an improved methodology for predicting the mined ores dilution when mining the PivdennoBilozirske field, supplemented by a more complete data set to increase reliability. The determined correlation relationship can also be the basis for improving and optimizing the design parameters of the mining system or developing the measures for strengthening the hanging wall rocks, for example, with rope bolts. 


\section{Conclusions}

1. A new comprehensive scientific and methodological approach has been developed to identify the degree of the geological and technological factors influence on the value of ore dilution factor. It is based on the analysis of the structure and properties of the host rocks in the hanging wall, the analysis of the technological parameters of stopes mined-out in contact with the host rocks, processing of actual surveying data of rockfall volumes and dilution factors, as well as constructing a 3D model of one of the Pivdenno-Bilozirske field floors.

2. The peculiarities have been revealed of the geological structure changing along the strike of the ore deposit with a characteristic distinguished tendency to decreasing the hardness of hanging wall rocks, the slope angle of the ore deposit, increasing the deposit thickness and replacing the morphological composition of the rocks from the northern flank towards the southern one. At the same time, the deposit can be divided into 3 characteristic differing areas: northern, central and southern.

3. New patterns and empirical equations have been determined for changing the ore dilution in the primary stopes depending on the type, hardness coefficient and the contact area of the hanging wall rocks with the inclined outcropping of the stopes. With a decrease in the rocks hardness from $f=11$ to $f=8$, a sharp increase in dilution factor by 2.2 times is observed. However, with a decrease in hardness from $f=15$ to $f=11$, the dilution factor increases by 1.5 times. With an increase in contact area of rocks with the stope, the dilution factor increases uniformly linearly, but with a slightly lower degree of influence than the hardness.

4. A multiple regression equation has been obtained of the relation between the stopes dilution of the floor $740-840 \mathrm{~m}$ with the rocks hardness within $f=11-15$ and the contact area of the stopes with the rocks $780-2010 \mathrm{~m}^{2}$. The regression model variability of $85.96 \%$ evidences its reliability and representativeness. The methodological approach proposed in the paper can be used to develop an improved methodology for predicting the mined ores dilution when mining the Pivdenno-Bilozirske field, supplemented by a more complete data set to increase reliability.

The authors would like to thank the technical managers PJSC "Zaporizhzhia Iron Ore Plant" for the information provided on the failure of hanging wall rocks into the stopes.

\section{References}

1. Mineralni resursy Ukrainy. (2018). Kyiv: Derzhavnyi informatsiinyi heolohichnyi fond Ukrainy. $\begin{array}{lllll}\text { Iron-ore deposits of } & \text { (2018). } & \text { Retrieved from }\end{array}$ https://www.photoukraine.com/russian/articles?id=171)

2. Shatokha, V. (2015). The sustainability of the iron and steel industries in Ukraine: challenges and opportunities. Journal of Sustainable Metallurgy, 2(2), 106-115. https://doi.org/10.1007/s40831$\underline{015-0036-2}$

3. Hrinov, V., \& Khorolskyi, A. (2018). Improving the process of coal extraction based on the parameter optimization of mining equipment. E3S Web of Conferences, (60), 00017. https://doi.org/10.1051/e3sconf/20186000017

4. Sadovenko, I., Inkin, O., \& Zagrytsenko, A. (2016). Theoretical and geotechnological fundamentals for the development of natural and man-made resources of coal deposits. Mining of Mineral Deposits, 10(4), 1-10. https://doi.org/10.15407/mining10.04.001

5. Timoshuk, V., Tishkov, V., Inkin, O., \& Sherstiuk, E. (2012). Influence of coal layers gasification on bearing rocks. Geomechanical Processes During Underground Mining - Proceedings of the School of Underground Mining, 109-113. https://doi.org/10.1201/b13157-19 
6. Stupnik, M., Kalinichenko, O., Kalinichenko, V., Pysmennyi, S., \& Morhun, O. (2018). Choice and substantiation of stable crown shapes in deep-level iron ore mining. Mining of Mineral Deposits, 12(4), 56-62. https://doi.org/10.15407/mining12.04.056

7. Byzylo, V., Koshka, O., Poymanov, S., \& Malashkevych, D. (2015). Resource-saving technology of selective mining with gob backfilling. New Developments in Mining Engineering 2015: Theoretical and Practical Solutions of Mineral Resources Mining, 485-491. https://doi.org/10.1201/b19901-84

8. Petlovanyi, M., Kuzmenko, O., Lozynskyi, V., Popovych, V., \& Sai, K. (2019). Review of manmade mineral formations accumulation and prospects of their developing in mining industrial regions in Ukraine. Mining of Mineral Deposits, 13(1), 24-38 https://doi.org/10.33271/mining13.01.024

9. Kuz'menko, A., Furman, A., \& Usatyy, V. (2010). Improvement of mining methods with consolidating stowing of iron-ore deposits on big depths. New Techniques and Technologies in Mining, 131-136. https://doi.org/10.1201/b11329-22

10. Petlovanyi, M., \& Mamaikin, O. (2019). Assessment of an expediency of binder material mechanical activation in cemented rockfill. ARPN Journal of Engineering and Applied Sciences, 14(20), 3492-3503.

11. Bini, C., Maleci, L., \& Wahsha, M. (2017). Mine waste: assessment of environmental contamination and restoration. Assessment, Restoration and Reclamation of Mining Influenced Soils, 89-134. https://doi.org/10.1016/b978-0-12-809588-1.00004-9

12. Popovych, V., Telak, J., Telak, O., Malovanyy, M., Yakovchuk, R., \& Popovych, N. (2020). Migration of hazardous components of municipal landfill leachates into the environment. Journal of Ecological Engineering, 21(1), 52-62. https://doi.org/10.12911/22998993/113246

13. Medianyk, V., Netecha, M., \& Demchenko, Y. (2015). Integrated production and utilization of mineral resources. Mining of Mineral Deposits, 9(1), 93-100. https://doi.org/10.15407/mining09.01.093

14. Petlovanyi, M.V., \& Medianyk, V.Y. (2018). Assessment of coal mine waste dumps development priority. Naukovyi Visnyk Natsionalnoho Hirnychoho Universytetu, (4), 28-35. https://doi.org/10.29202/nvngu/2018-4/3

15. Forster, K., Milne, D., \& Pop, A. (2007). Mining and rock mass factors influencing hangingwall dilution. Rock Mechanics: Meeting Society's Challenges and Demands, 1361-1366. https://doi.org/10.1201/noe0415444019-c169

16. Pysmennyi, S., Brovko, D., Shwager, N., Kasatkina, I., Paraniuk, D., \& Serdiuk, O. (2018). Development of complex-structure ore deposits by means of chamber systems under conditions of the Kryvyi Rih iron ore field. Eastern-European Journal of Enterprise Technologies, 5(1(95)), 33-45. https://doi.org/10.15587/1729-4061.2018.142483

17. Khomenko, O., Kononenko, M., \& Petlyovanyy, M. (2014). Investigation of stress-strain state of rock massif around the secondary chambers. Progressive Technologies of Coal, Coalbed Methane, and Ores Mining, 241-245. https://doi.org/10.1201/b17547-43

18. Stupnik, M., Kolosov, V., Pysmennyi, S., \& Kostiantyn, K. (2019). Selective mining of complex stuctured ore deposits by open stope systems. E3S Web of Conferences, (123), 01007. https://doi.org/10.1051/e3sconf/201912301007

19. Henning, J.G., \& Mitri, H.S. (2007). Numerical modelling of ore dilution in blasthole stoping. International Journal of Rock Mechanics and Mining Sciences, 44(5), 692-703. https://doi.org/10.1016/j.ijrmms.2006.11.002

20. Xia, K., Chen, C., Zheng, Y., Zhang, H., Liu, X., Deng, Y., \& Yang, K. (2019). Engineering geology and ground collapse mechanism in the Chengchao iron-ore mine in China. Engineering Geology, (249), 129-147. https://doi.org/10.1016/j.enggeo.2018.12.028

21. Khomenko, O., Kononenko, M., \& Petlovanyi, M. (2015). Analytical modeling of the backfill massif deformations around the chamber with mining depth increase. New Developments in Mining Engineering 2015: Theoretical and Practical Solutions of Mineral Resources Mining, 265-269. https://doi.org/10.1201/b19901-47 
22. Villegas, T., Nordlund, E., \& Dahnér-Lindqvist, C. (2011). Hangingwall surface subsidence at the Kiirunavaara Mine, Sweden. Engineering Geology, 121(1-2), 18-27. https://doi.org/10.1016/j.enggeo.2011.04.010

23. Lyashenko, V.I., \& Golik, V.I. (2014). Remedies for geomechanical monitoring of a rock massif in underground development of ore deposits. Gornyi Zhurnal, (5), 47-51.

24. Khorolskyi, A., Hrinov, V., Kaliushenko, O. (2019). Network models for searching for optimal economic and environmental strategies for field development. Procedia Environmental Science, Engineering and Management, 6(3), 463-471.

25. Saik, P., Petlovanyi, M., Lozynskyi, V., Sai, K., \& Merzlikin, A. (2018). Innovative approach to the integrated use of energy resources of underground coal gasification. Solid State Phenomena, (277), 221-231. https://doi.org/10.4028/www.scientific.net/ssp.277.221

26. Bondarenko, V.I., \& Sai, K.S. (2018). Process pattern of heterogeneous gas hydrate deposits dissociation. Naukovyi Visnyk Natsionalnoho Hirnychoho Universytetu, (2), 21-28. https://doi.org/10.29202/nvngu/2018-2/4

27. Chistyakov, E., Ruskih, V., \& Zubko, S. (2012). Investigation of the geomechanical processes while mining thick ore deposits by room systems with backfill of worked-out area. Geomechanical Processes During Underground Mining - Proceedings of the School of Underground Mining, 127-132. https://doi.org/10.1201/b13157-23

28. Emad, M.Z., Vennes, I., Mitri, H., \& Kelly, C. (2014). Backfill practices for sublevel stoping system. Mine Planning and Equipment Selection, 391-402. https://doi.org/10.1007/978-3-319$\underline{02678-738}$

29. Fu, Z. (2018). The mechanism of imported iron ore price in China. Modern Economy, 09(11), 1908-1931. https://doi.org/10.4236/me.2018.911120

30. Petlovanyi, M. (2016). Influence of configuration chambers on the formation of stress in multimodulus mass. Mining of Mineral Deposits, 10(2), 48-54. https://doi.org/10.15407/mining10.02.048

31. Bondarenko, V., Cherniak, V., Cawood, F., \& Chervatiuk, V. (2017). Technological safety of sustainable development of coal enterprises. Mining of Mineral Deposits, 11(2), 1-11. https://doi.org/10.15407/mining11.02.001

32. Zhan, F.L., \& Ye, P. (2014). Construction techniques and mechanism of pre-anchoring fissured stope hangingwall by fully-grouted cable bolts. Applied Mechanics and Materials, (580-583), 283-286. https://doi.org/10.4028/www.scientific.net/amm.580-583.283

33. Petlovanyi, M., Lozynskyi, V., Zubko, S., Saik, P., \& Sai, K. (2019). The influence of geology and ore deposit occurrence conditions on dilution indicators of extracted reserves. Rudarsko Geolosko Naftni Zbornik, 34(1), 83-91. https://doi.org/10.17794/rgn.2019.1.8

34. Kuzmenko, O., Petlyovanyy, M., \& Heylo, A. (2014). Application of fine-grained binding materials in technology of hardening backfill construction. Progressive Technologies of Coal, Coalbed Methane, and Ores Mining, 465-469. https://doi.org/10.1201/b17547-79

35. Zhao, X., \& Niu, J. (2020). Method of predicting ore dilution based on a neural network and its application. Sustainability, 12(4), 1550. https://doi.org/10.3390/su12041550

36. Russkikh, V.V., Lapko, V.V., \& Zubko, S.A. (2012). Development and adoption of new technical decisions for development of Yuzhno-Belozerskoye ore deposit under difficult mining and geological conditions. Naukovyi Visnyk Natsionalnoho Hirnychoho Universytetu, (5), 34-38. 